\title{
Inter-American Encounters in the Travel and Migration Narratives of Mayra Montero and Cristina García: Toward a Decolonial Hemispheric Feminism
}

\footnotetext{
$\mathrm{E}$
} mpire's acts of epistemic violence upon its others, women and the native informant, have been central themes of travel and migration narratives. In its early modern iteration, the travel genre encapsulated the knowledge production of European travelers, who cultivated the genre with the aim of rendering the European superior (Pratt 1992, 5-6). Mobility, in these cases, resulted from the voluntary travel of Europeans in circuits of limited duration. Conversely, the migration narrative, which emerged during the massive migrations along the North-South axis that resulted from changing labor patterns in the late modern period, represents migrants' struggles with the construction of their identities as peripheral in home and host nations. Mobility in the migration narrative is an effect of the involuntary and often enduring epistemic and physical dislocation of colonial subjects resulting from the ongoing effects of Anglo-European hegemony.

But what if travel and migration narratives were not considered separate genres, albeit with analogous concerns, but rather understood as dialectically related? What if we read the travel narrative as embedded within the migration narrative, mobilizing its oppressive logic into new terrains? Mary Louise Pratt (2008) has shown how Latin American writers of the high modernist period inverted the travel genre, adopting its conventions to create a counterhistory by expressing a view from "the position of the people [traveling] and places traveled to" (466). Telling the story from the point of view of its reception, she argues, disrupts the hierarchical ordering of European-American relations, allowing for a renegotiation of asymmetrical identities and relations between the neocolony and the metropole (467-75). I suggest that the migration narrative also contains perspectival inversions reflecting the migrant's subalternization as well as his or her internalization of the coloniality that produced subaltern subjectivities in the first place.

I would like to thank the three anonymous reviewers for their very helpful comments on an earlier draft of this essay.

[Signs: Journal of Women in Culture and Society 2014, vol. 39, no. 2]

(C) 2013 by The University of Chicago. All rights reserved. 0097-9740/2014/3902-0010\$10.00 
In this essay I explore contemporary travel and migration narratives of inter-American encounters as dialectical permutations of historically continuous, evolving forms of interaction that function within the repressive logic of coloniality of power. An analysis of Mayra Montero's In the Palm of Darkness (1997), a travel narrative, and Cristina García's The Agüero Sisters (1998), a mixed travel and migration narrative, yields examples of the complex grafting of coloniality's violence onto the native informant and onto women within hemispheric relations. It also reveals examples of disruptions of the subalternizing processes of coloniality. Aníbal Quijano (2008) defines coloniality of power as the structure of racial domination that characterized Spanish colonizers' power over the colonized. It also refers to subsequently elaborated geocultural discourses pertaining to the humanistic sciences that Europe disseminated to its periphery, thereby legitimating its racial-ethnic and epistemic superiority.

In the past decade, there has been increased scholarship on cross-border hemispheric feminisms. US Latina scholars have advanced understanding of the economic and sociopolitical issues transcending national borders and their impact on US Latina and Latin American women, aiming to promote coalition building around common concerns (Acosta-Belén and Bose 2000, 1114). Latin American feminist Claudia de Lima Costa $(2006,63)$ notes the "formidable roadblocks" for feminist cross-border dialogue, caused in part by histories of exclusion within and across North-South borders. Literary and cultural workers have tended to take as their subjects the plights of citizens originating within nations that they call home. Yet, with the extraordinary displacements of peoples within the hemisphere, critics have reconceptualized the notion of national literatures and the boundaries of citizenship and community (Rosario 2010, 14). Montero and García's novels exemplify such conceptual shifts. ${ }^{1}$ Montero's work has been studied as part of a pan-Caribbean literature (Rivera 2001, 127; Alcocer $2005,127)$. García's works have been studied within the Caribbean diasporic literary canon (Aguerrevere 2005; Irizarry 2006). But they have also been included in the US Latina/o canon (Kandiyoti 2006; Dalleo and

\footnotetext{
${ }^{1}$ Montero and García are well-known novelists. Montero was born in Havana in 1952 and has lived in Puerto Rico since the mid-1960s. She has written ten books, all in Spanish. Many of her novels, including Messenger (1999), The Last Night I Spent with You (2000), The Red of His Shadow (2001), Captain of the Sleepers (2005), and Dancing to "Almendra" (2007), have been translated into English and other languages. García was born in Havana in 1959 and immigrated to the United States in 1960. She has written six novels, all in English. These include, besides the novel under analysis, Dreaming in Cuban (1992), Monkey Hunting (2003), A Handbook to Luck (2007), The Lady Matador's Hotel (2010), and King of Cuba (2013).
} 
Machado Sáez 2007, 107-31). A feminist hemispheric approach validates these revised canon formations while recognizing the necessity of expanding the arena of comparative inquiry, allowing new questions to be asked about inter-American relations (Pérez Firmat 1990; Benítez-Rojo 1992). In terms of coloniality of power, we might ask: What are the experiences and contestations of coloniality on both sides of the North-South axis? What strategic interventions have feminists made on the northern side of the North-South divide to help shift the location of knowledge from the epicenter of the Americas to the periphery, thereby disrupting the histories of exclusions to which Costa refers?

I adopt a feminist, cross-border, hemispheric perspective to address these questions. While sharing commonalities with Gloria Anzaldúa's border feminism, a cross-border hemispheric feminism conceives the notion of borders differently in the context of Caribbean nations. Anzaldúa's borderlands point to a physical border that excludes as well as extends possibilities for uniting peoples on both sides of the border, such as that of the Rio Grande. The Cuban-American borderlands as well as those uniting or separating peoples of the Caribbean diaspora are characterized by extraterritoriality. As Ada Savin $(2003,66)$ notes, Cuba is really two nations divided by an ocean, with residents of both seeking legitimacy as citizens. The same could be held for exiles from other nations of the Caribbean diaspora. In this context, cross-border hemispheric feminism is defined as an oppositional ideological or epistemological location from which feminists along the NorthSouth axis combat the power that regimes based on coloniality on both sides of the border exercise to alienate and exclude.

I also analyze Montero's and García's novels as hemispheric in their approach in another sense, as adaptations of what Gustavo Pérez Firmat refers to as the "mediative approach" (1990, 3-4), represented by texts that have a comparative or inter-American dimension already embedded within them. Travel and migration narratives epitomize just such an approach. This is because the characters embodying the mental schemas informing coloniality and decoloniality travel and migrate across hemispheric borders.

A comparative analysis of Montero's and García's novels facilitates a feminist decolonial perspective on inter-American encounters. Both narratives focus on colonial difference - the site of the conflictual encounter between Western scientific paradigms, including Spencerian positivism, Darwinism, and philosophical liberalism, and non-Western paradigms specific to the Caribbean, vodou and Santería. In what follows, I introduce coloniality and decolonial feminism and show how these concepts drive the epistemic struggles between modern Western and non-Western subjects in their narratives. 


\section{Coloniality and decolonial feminisms}

Quijano links coloniality to the racial division of the world's population that began with the colonization of America. The ideological codification of racial difference rested on supposed differences in biological structure that naturalized relations of superiority and inferiority between the colonizers and the colonized (Quijano 2008, 182-89). The results of the history of colonial power are that peoples of the Americas were dispossessed of their historical identities and their cognitive models were relegated to the past or premodern world (200). Quijano further affirms that coloniality is constitutive of modernity (189). Coloniality is not exclusively an effect of the consolidation of empire and global markets through which Spain and then the rest of Europe imposed dominance through colonialism; it is primarily an epistemological or ideological model of power that precedes and exceeds colonialism. Cultivated within humanistic and social science discourses, coloniality engendered a cultural imaginary that became embedded in social and cultural relations, producing new social identities: the European as the modern subject and both the subaltern (blacks, Indians, and mestizos) and women as nonmodern (197-200). A primary consequence of the naturalization of the European and subaltern subjectivities was the denial of coevality, that is, the refusal to recognize that European and subaltern knowledges exist in the same space and time and, as such, constitute the new intersubjective relations that informed modernity in the hemisphere (195). Outside of this dominant point of view, Quijano posits a view of modernity as a five-hundred-year world historical process in which different social collectivities from each temporal and spatial domain articulate different rationalities (194).

The concept of coloniality of power, as articulated by Quijano, pushes against dominant trends in postcolonial studies, produced in academic departments in the United States, that portray Latin America and the Caribbean, along with other colonized countries, as having overcome colonialism with independence in the nineteenth and twentieth centuries. It also pushes against the homogeneous portrayal of a subalternization of knowledges across the Caribbean and Latin American nations, as espoused by Latin American historians, in its attempts to specify the differences in type and degree of colonial power (Salvatore 2010, 341-43).

In his Local Histories/Global Designs, Walter D. Mignolo (2000, 93-94) also argues that the first modern discourse is informed by the geocultural imaginary of racial-ethnic superiority, or Occidentalism, that became embedded in the everyday life of the dominators and the dominated. Mignolo coins the concept "locus of enunciation" (120-21) to indicate the site from which discourses of Occidentalism can be elaborated or resisted. From the 
perspective of Occidentalism, the preexisting signifying systems of the Americas are perceived as nonmodern. Decolonizing the locus of enunciation requires foregrounding the site of colonial difference - that is, the racial classification of the planet in the colonial imaginary and how it creates the other and the other's knowledge as nonmodern (13).

A decolonial discourse or border thinking would foreground those moments where "the imaginary of the modern world system cracks" (Mignolo 2000, 23). The locality of subaltern knowing is like a border, an inside and outside: “'Border thinking' is still within the imaginary of the modern world system, but repressed" (23). Mignolo uses the term "border gnoseology" to designate a discourse on colonial knowledge that focuses on the "conflictive intersection" of the European or modern/colonial perspective and what he calls "colonial modernities" derived from the Americas (11). Mignolo views the Caribbean and Creoleness as a privileged site of a border gnosis and gnoseology. Following Jean Bernabé, Patrick Chamoiseau, and Raphaël Confiant, authors of Éloge de la Créolité (In praise of Creoleness; 1993), Mignolo presents créolité as a mode of being in relation to a local history, conceived and defined by French colonization and a plantation economy, but also as a world experience that points beyond, to decolonization. Créolité involves "encroaching a form of being into a dominant one but from the perspective of the subaltern" (Mignolo 2000, 243). Coloniality, Mignolo underscores, transcends historical colonialism, shapes neocolonialism, and drives nation-building projects, revealing "different rhythms and energy according to its spatial and historical location within the modern/colonial world system" (43).

María Lugones (2010) adds to the discourses on coloniality by introducing gender as a fundamental component. Lugones explains that when we conceive of oppressed people as something more than oppressed, it becomes possible to shift focus to resistance. The shift occurs when we inhabit the site of colonial difference, where colonial imposition resides alongside the "resistant presence, the active subjectivity of the colonized" (749). Lugones's feminist border thinking offers a resistant reading that feminists on both sides of the border can adopt. It consists of a reading of the cross-border encounter between oppressing or resisting relations that disidentifies with the "social-scientific objectifying reading" (Lugones 2010, 753).

The construct of the resistant subaltern, as espoused by Lugones and Mignolo, is further nuanced by reading it against the theorizations of subaltern subjectivities produced by Caribbean scholars. David Scott (2004) draws not on a rhetoric of resistance, which he links to an exhausted romantic storyline, but on a rhetoric of tragedy that takes into account our 
present perspective on the failure of hemispheric anticolonial struggles. A tragic narrative forces reflection on the difficulty of erasing the past's imprint on the present (Scott 2004, 135). Our analysis should focus, Scott suggests, on how modern colonial power positively constituted the heterogeneous elements of life in modernity, now including past forms of social interaction, knowledge systems, and family systems. The emphasis should be on how these elements are produced by subaltern subjects, who, as conscripts of the modern structure of slave plantation power, are partially constituted through that structure (114-23).

Sibylle Fischer (2004) similarly articulates heterogeneity as an intrinsic condition of modernity. The plantation economy produced a modern consciousness only in a heterogeneous sense, engendering instrumental knowledge that legitimated enslavement but also creating noninstrumental structures, such as secret societies, that facilitated the reinvention of traditions and belief systems. In order to understand modernity as a transculturizing process, it is necessary to "read against the grain, with an ear for improbable distortions, so that they might reveal the shadow of other futures, of projects not realized and ideas rarely remembered" (Fischer 2004, 23). Fischer uses the term "disavowed modernity" (37) to indicate a conflictive stance toward the past that includes strategies for repudiating the past. Yet the strategies are half measures, triggering a recognition of what is disavowed (37-38).

Together with the aforementioned scholars, I examine Western and nonWestern knowledge as coeval systems within asymmetrical power relations of modernity, and I track the mutual constitution of these systems through the conflictive encounters of Anglo-Europeans and their others. I am attentive to how the authors of the novels struggle to bring into the reader's imaginary the conditions under which heterogeneous modern subjectivities became formed and the possibilities such subjectivities offer for expanding Western knowledge beyond our present means and aims.

\section{The travel narrative}

In Imperial Eyes, Pratt (1992) notes that the travel narrative, in its merger with the scientific enterprise, was a modern project that launched a European knowledge-building endeavor on a planetary scale. Europe's increased technological capacity allowed Europeans to preserve, transport, display, and document specimens. It also triggered new genres of professional writing, including treatises on animal taxonomies, journalism, and narrative travel accounts (Pratt 1992, 29). Montero's In the Palm of Darkness is an exemplar of the modern European travel narrative. The narrative weaves 
together the life stories of two men: Victor Grigg, a US herpetologist sent to Haiti by Vaughan Patterson to rescue the grenouille $d u$ sang, or blood frog, from extinction, and Adrien Thierry, his Haitian guide, vodou priest, pwazon rat (zombie hunter), and frog hunter. The mission spares Grigg from confronting the news that his wife has left him for a woman. His arrival coincides with the forced exile of President Jean-Bertrand Aristide, during which time the Tontons Macoutes, the thuggish paramilitary force, were crushing popular opposition and reinstating their drug trade. In spite of dangerous encounters with the Macoutes and rival religious sects, Grigg successfully retrieves the frog, but he later drowns, as does Thierry, when the ship they board for their return sinks.

Montero's narrative imitates the travel genre, exposing the ideological processes by which Enlightenment travel writing produced and justified Anglo-European hemispheric hegemony. Through an exploration of the figurative possibilities of the phrase "survival of the fittest" and by tracing a motif of connotative meanings and images associated with blood, Montero shows how Europeans relied on metaphorical thinking shaped by science to render their knowledge superior. Herbert Spencer's coinage of the phrase "the survival of the fittest," which treats society as an organism, transformed Darwin's notion of natural selection, originally conceived as a struggle for biological survival, into a contest between social groups that signified the superiority of one nation, race, or gender over the other. Spencer cemented the idea that human nature is continuous with animal psychology (Hawkins 1997, 31). The metaphor of blood reinforces the repeated references to survival. To be of a particular blood is to be of a particular racial ancestry. Indeed, the metaphor of blood within hereditarian discourses has served, since the latter half of the nineteenth century, as "code for race" (Szkupinski Quiroga 2007, 145). Within historical and contemporary discourses of race, the metaphor is also suggestive of a whole relay of racially hierarchical encodings, including beliefs regarding the mixing or tainting of blood, the notion of the sanctity of blood, and emotions of fear and anxiety around such unexamined beliefs (Szkupinski Quiroga $2007,145,150)$. For Spencer, the metaphor extends beyond race to include age, class, and gender. He thus specifies that children, the lower classes, and women, in addition to tribal peoples, reflect a more primitive evolutionary state characterized by immorality and irrationality. Inheritance, operative in the fittest, distinguishes those who progress from those who regress (Hawkins 1997, 98-99).

Grigg's worldview originates in this metaphorical system. He is thus led to conceive his relationship with Thierry as one between master and slave, mirroring relations between whites and nonwhites in Haiti under French 
colonial rule and, subsequently, under British and American neocolonial rule. Wishing to serve as guide, Thierry engages Grigg on the dominator's own terms, using the knowledge he learned as a boy when he served as guide to herpetologist Wilbur Jaspers, whom he affectionately called Papa Crapaud (Papa Toad). Viewing their relationship through the lens of competition, Grigg interprets Thierry's knowledge as an appropriation of his own knowledge. In their first interview, Grigg remains silent when Thierry completes Grigg's preliminary sketches of the frog, trying to "gain a few moments" - probably to plot how to reestablish the master-slave relationship (Montero 1997, 19).

Thierry reorders relations again on the Mont des Enfants Perdus when he insists that they leave because the Macoutes will kill those who trespass on their site of business. Resentful, Grigg at first refuses to leave, representing himself as innocent: "Nothing very serious can happen to a man when all he looks for, all he wants, is a harmless little frog" (Montero 1997, 41). Grigg deploys here a colonial mechanism that Pratt refers to as "anti-conquest" (1992 7), whereby the European bourgeois subject sought to demonstrate innocence in the moment he acted to establish hegemony. This is the man "whose imperial eyes passively look out and possess" (Pratt 1992, 7).

Thierry again surpasses Grigg's knowledge when he informs Grigg on their way down the mountain that he had heard the blood frog sing twice the previous evening; this comes after Grigg tells him he had not heard it. Grigg takes this claim as a lie and an appropriation, which explains his decision to dismiss Thierry. At the hotel, when Thierry further emphasizes that the drug lords are the masters of the mountain, Grigg views Thierry as a traitor: "He walked out of the room, not making a sound, and I was reminded of Bengali servants in the movies, the ones who always end up stabbing their masters" (Montero 1997, 66).

Grigg finally finds a solution for maintaining his self-concept as the fittest: suppression. Following his capture of the specimen on Casetaches Hill, he implies in his report that there was no frog on the Mont des Enfants Perdus. He portrays the one he found on Casetaches Hill as "the last of its species on earth" (Montero 1997, 182). The journalist whose newspaper clipping about frog extinction in Haiti appears on the last page of the novel uses this report as his source. The text's irony plays off the different narrative levels. The reader is obliged to suspect what is subsequently taken as truth by the narrator, the journalist, and his readership. Grigg, the Anglo-American traveler, does not return to the epicenter. While his report does return, the reader knows the lie. Montero decolo- 
nizes the locus of enunciation by foregrounding the site of colonial difference: she elaborates coloniality as Grigg's construction of Thierry's knowledge as nonknowledge, and she exposes Grigg through her transgressive play with what Kezia Page calls the "cultural remittances" (2011, 7-14) of the Caribbean diaspora, the messages that become infused in the remitted product invoking questions of identity, the authorization of knowledge, and audience.

The instrumental motivation driving Grigg's knowledge production about species extinction is also evident in his scientific labor in postAristide Haiti. This labor includes writing the names of specimens on small cards, filing the cards, taping and transcribing, catching and placing specimens in jars, listening to or taping their calls, reading scientific journals, writing diary entries, and mailing reports. His pride in being selected from among his peers to fulfill Patterson's mission-one that, if successful, will be rewarded with a two-year research fellowship - reflects his belief in his national status as the fittest. His attitudes and actions are continuous with the logic of coloniality driving the neocolonial acts of the US government. As Anglo-Saxon and North American, he feels entitled to appropriate resources from nations comprising the Americas in order to secure AngloAmerican discovery while disregarding the political turmoil of a military coup and the instatement of a provisional military-backed government that the United States supported to eliminate the spread of communism in the region (Farmer 2003).

The blood frog further refunctionalizes colonial relations through its metaphorical status, suggested by its very name, along with its connection to the metaphor of the fittest. Grigg translates his interest in continuity and extinction, first applied to the frog, to the social world. His attentiveness to skin color as the boundary separating the subjects and objects of knowledge is evident in his meeting with Emile Boukaka, a surgeon who has expertise in herpetology. In the waiting room, Grigg notices a postcard on a bulletin board depicting three naked Indian women squatting and cooking with an old man, naked as well. The caption reads: "Indian Hut, Beni Bolivia” (Montero 1997, 93). When the doctor enters the room, Grigg views him through the photographic image, reflecting on his blood status. Given his profession, Grigg had "an image of him as a tall gray-haired light skinned man with spectacles, more self-conscious, less chubby and tropical than he actually was" (93). Instead, a gentleman appears who is "intensely black, the skin on his arms gleamed as if he had been born in Africa" (93). Grigg then looks further, assessing the classification of the racial mixture of indigenous, African, and European blood he detects in 
the figures portrayed on the postcard against Boukaka's physiognomy: "He had an enormous round, flat face, a face like a Mexican (or Bolivian?) tortilla patted into shape by naked Indian women. There, in the fat circle of that face, his nose, his bulging eyes, his thick half-smiling lips seemed to be dancing" (93).

Like other Caribbean women writers, Montero uses the postcard as a mechanism to work against the suppressing, binary logic of coloniality while reconstructing the Caribbean modern subject in its full heterogeneity. In her discussion of the postcard as artifact, Donette Francis (2010) notes the possibilities it offers for reinserting subaltern subjectivities into the historical archive and for expanding racial categories beyond the blackwhite polarizations reflective of the realities of the modern colonial world system. In Montero's narrative, the reader, like Grigg, is obliged to look differently at this hybridized image and heterogeneous figure, to look outside of hegemonic preconceptions, in order to acknowledge Boukaka as a modern subject (Francis 2010, 141-43).

Grigg also attempts a taxonomy of Thierry's physiognomy based on the same logic in their first encounter, leading to Grigg's negative judgment of him: "Thierry looked too old, even sickly somehow. . . Since he was missing some teeth, the tip of his tongue, an immensely pale tongue, protruded whenever he talked, and I concluded that in the field at midnight, setting out on the difficult treks of an expedition, this man would not be of much use to me" (Montero 1997, 18-19). ${ }^{2}$ Grigg's taxonomy is not an innocent description but rather an ideological codification of racial difference that naturalizes relations of superiority and inferiority between the colonizers and the colonized. It prefigures the reproduction of interactions within a racial hierarchy and also explains Grigg's anger when Thierry creates the cracks in this ideological system.

The metaphor of blood also illuminates the internal needs driving Grigg's solipsistic model of knowledge that reproduces gender hierarchies. Grigg's scientific travel reflects an unconscious aim to inhabit science as a refuge from anxieties around maternal, female attachment and separation. ${ }^{3}$ While meditating on his wife Martha's betrayal, he recalls a painting of a frog that his mother, an artist, made when she was pregnant with him and

\footnotetext{
${ }^{2}$ Rudyard J. Alcocer (2005) notes that a focus on blood reveals a "hereditarian imagination" (3) in Caribbean narrative, which is informed by cultural elements unique to the region, such as the relationship between the plantation, race, and history. Caribbean writers challenge the deterministic nature of hereditarian discourses by developing an alternative imaginary based on ethnic heterogeneity (Alcocer 2005, 3-5).

${ }^{3}$ My analysis of male autonomy is indebted to Evelyn Fox Keller's object relations theory $(1985,79-98)$.
} 
later gave to him when he left home to study zoology at the university. The title, Alytes obstetricans (The midwife toad), refers to a species of toad that carries fertilized eggs on its back until they hatch. The painting invokes an analogy between the human fetus and the frog: the boundaries separating and protecting them from external pollutants is a viscous membrane through which they absorb nutrients for survival, in the case of the human fetus drawing on the bloodstream of the mother. Grigg recalls his mother's ambivalence about her pregnancy: "She hated many things but more than anything else, she hated batrachians" (Montero 1997, 21).

The memory suggests that Grigg's motivation for pursuing the blood frog-another species of batrachian - is to salvage his autonomous self from extinction. But it also simultaneously reveals the overdetermination of maternal, female attachment that he cannot successfully resolve. When he finally captures the frog, Grigg likens it to the innocent human fetus, "a small shining piece of viscera" (Montero 1997, 171). Capturing this one male frog seems to ensure his own survival and autonomy as the privileged subject and to ward off anxieties of attachment and separation in relation to the maternal, female body. These anxieties culminate in his fantasies about Martha's lesbian relationship, juxtaposed with his thoughts about his mother, in which he again shows concern over the loss of his status as masculine subject and over the status of the subject-object relationship. He wonders: "Who seduced whom, which of them took the initiative, what did they say about me"? (78).

While Grigg separates the knower (subject) and the known (object) to achieve scientific knowledge in the name of survival-concealing even to himself the unconscious, irrational desires and fears regarding women that drive his knowledge-gathering processes-Thierry, as priest and zombie hunter, seeks connectivity as a mechanism for wisdom in the name of survival. Thierry uses vodou to engage Grigg's Western scientific practices and in so doing responds to the conditions of the modern world with a different logic. Thierry is a paradigmatic exemplar of the heterogeneous modern subject, or Creoleness. He creates fissures in the imaginary of the modern social world through his border gnoseology, his intervention in coloniality at the conflictive intersection of the knowledges of the European and the American subaltern. Thierry creatively juggles the diverse Caribbean modes of being and knowing that resulted from the dynamic merging of European knowledge and Afro-Caribbean signifying practices, kept alive within slave societies. Vodou, emerging from various regions of West Africa, reflects a syncretic blending of African belief systems with Catholic liturgical traditions and includes folk medicinal practices, myths, and religious rituals. Of importance here is how the rituals facilitated distinct ways of 
being and knowing. The power of the gods or loas is concrete and localized, adapting to historically specific situations and social structures (Dayan 1997, 25-27).

Thierry's stories, interventions, and ritualistic teachings, integrated into and a product of social life, are not motivated by a desire for the mastery of nature but by authentic concern for the survival of the blood frog species, which he sees as connected to human survival. Thierry's attempt to submit Grigg to the water ritual engages two teachings, both designed to help Grigg become conscious of his disavowal of maternal, female attachment in order to avoid the destructive consequences of his disavowal. In one of his recorded conversations, he tells Grigg that he could have caught the blood frog when working under Papa Crapaud but feared that a great punishment could result from killing the specimen since so many people were in pursuit of it; if he let it live, it would return to the loas, its "natural masters," and appease them (Montero 1997, 30). He thus suggests that the extinction of frogs is a byproduct of broader social forces, such as the fragility of human connection and memory. He links survival not to separation from the mother and other ancestors but to his connection with and remembrance of the ancestors. He tells Grigg that following his decision to let it go, he offered a prayer to his dead mother to protect him (31).

Thierry's second teaching addresses Grigg's relationship with Martha. In preparation for the ritual, which is in large part self-reflexive, Thierry first thinks back on Papa Crapaud's psychological dispossession, which was caused by his incapacity to control Ganesha, a woman he had brought back with him from one of his frog hunts. Papa Crapaud's life had spiraled out of control, Thierry recalls, as the herpetologist became obsessed with this woman of East Indian descent, whom he had met at the port of Guadeloupe, where she was peddling frog figurines. Thierry then tells Grigg that he regrets his own sexual relations with Ganesha, a transgression against Papa Crapaud. Thierry explains that in order to atone for his own previous sins, he will now instruct Grigg in the ritual. He then suggests that he and Grigg should now ask the master of the waters to extinguish Grigg's passion and return him to reason: "Blessed be Agwé Taroyo. . . . The water puts out the flame" (Montero 1997, 73). As Joan Dayan (1997) explains, the ritual allows the gods or loas to possess the believer. Possession allows the believer to understand how one's present circumstances are framed by historical and cosmic contexts (Dayan 1997, 16-17). Under conditions of forced dispersal, the loas' ties to a particular place of origin or lineage are no longer retrievable. They are now obliged to live under the waters, where they share space with the ancestors in an unspecified place called Guinea. 
Grigg's unwillingness to participate in the ritual is motivated by his resistance to relinquishing mastery over the native informant and women: "My wife left me, Thierry. I don't want to talk about water. When do you think we'll be able to climb the mountain?" (Montero 1997, 78). The reader is asked to be conscious of what Grigg repudiates - his attachment to Martha and to his mother as well as the coevality of Thierry's knowledge. But the denial is only partially achieved; what is repressed, as Fischer notes, comes back more strongly. Grigg's zombification, his dispossession, seals his fate. Ironically, the reader is made aware of his fate-death by the suppression of love-in the first line of the novel, when Grigg recalls with ridicule what a Tibetan astrologer had told Martha about him, that he "would die by fire" (1). Grigg is now returned to the loas: his disavowal results in the waters ultimately consuming him before he has a chance to attain self-consciousness.

Montero creates a truncated version of Georg Wilhelm Friedrich Hegel's master-slave dialectic that Susan Buck-Morss (2009) analyzes as being based on his knowledge of the Haitian Revolution. In the fully developed master-slave dialectic, the master believes himself to be independent of the slave and then realizes he is dependent on the slave for his wealth; the slave, for his part, believes himself to be dependent on the master but gains awareness of himself as independent subject who performs the labor of producing commodities (Buck-Morss 2009, 53-54). In Montero's text, however Grigg remains in a state of false consciousness. He continues to view himself, the master, as independent and Thierry, the slave, as dependent.

Montero not only uses Grigg to reveal the micro-level interactions of coloniality but also to reveal the coloniality inherent in the mental structures driving the Duvalierist Haitian state, permeating the psyches of its citizens, and ultimately undermining Aristide's anticolonial or decolonial state. Grigg's master-slave interactions and his hierarchical cataloging of human and animal species are continuous with François "Papa Doc" Duvalier's noiriste ideology, one that legitimized black control of the Haitian state. While it reverses the terms of coloniality, Duvalier's ideology remains within coloniality's same logic. As Valerie Kaussen shows, Duvalier implemented political models based on the master-slave relationship, but with the black class as master, as a solution to the problem of the internalization of colonial relations $(2005,71)$. These modes of thought bind hemispheric neocolonial relations, manifested in the US military occupation of Haiti from 1915 to 1934 and later in the US-backed ousting of Aristide toward the end of the century, which aimed to rid the hemisphere of communist rule (Farmer 2003). 
But coloniality does not have the last or only word. Montero uses Thierry's stories about his life not only to relay teachings to his interlocutor but also to close up the gaps in the historical archive. Thierry portrays himself, his family, and his community in a manner that brings to the center other truths once disavowed: the history of the ravages of coloniality in its various forms - internalized colonial relations, nation building, and neocolonial projects - from a subaltern perspective. While Grigg's knowledge is limited to what he can see or hear, Thierry's is based on a deep understanding of the entire social and natural context. The messages that he must interpret, from the dead corpses on the mountains or from the disfigured corpse seen upon entering the city of Jérémie, require a decoding of the social environment and the circulation of power relations within it. For instance, in examining the disfigured corpse at their entrance to Jérémie, he can identify the sect that was responsible as well as the reason for the brutal act based on the fact that the index finger of the left hand was missing, which, as Thierry asserts, "was like a message" (115).

Thus, while Grigg pursues his object with total disregard for the social environment that contains and defines the object and subject, Thierry pursues the object in a way that shows the interconnection between the knower and the known. While Grigg begrudgingly records Thierry's stories to learn about the frog's natural habitat, ignoring everything except parts concerning the frog, Thierry views his encounters with the specimen as enmeshed in everyday life, which is why he does not separate the destiny of his ancestors and his own life from the specimen's. Through the stories of his own life, Thierry provides a positively constituted alternative epistemological and ethical perspective that challenges Grigg's own illusory perspective, one that Grigg designed to reflect the superiority of his own sense-making mechanisms.

\section{The migration narrative}

In contrast to the conventional European travel narrative, one that justifies the Anglo-European frame of reference, the conventional migration narrative offers a subaltern perspective on loss of cultural identity, socioeconomic marginalization, nostalgia for home, assimilation, and social power (Rosario 2010). García's The Agriero Sisters, however, provides some twists on the conventions of this genre. The novel focuses on Constancia, a middle-aged woman who was forced to migrate to the United States following the Bay of Pigs invasion, and Reina, her estranged half-sister, who remains in Cuba. From their father Ignacio, a biologist, the sisters share an inheritance: a model for human relations based on rivalry. Ignacio's 
murder of his wife, Blanca, his cover-up of the crime, and his suicide are a mystery to the daughters, and the narrative action begins and ends with the solving of this mystery. The novel alternates between Ignacio's embedded autobiographical narrative and a series of third-person narratives centering on Constancia, Reina, and their family members. These are set in the early 1990s in different parts of the United States, Cuba, and Spain, while Ignacio's narrative is set in pre-Castro Cuba and is distinguished by a cursive script; the reader discovers only at the end of the novel that Ignacio's narrative is a handwritten manuscript that he left behind with other personal belongings in Camagüey, the village of his birth.

Ignacio's manuscript is a travel narrative. García, like Montero, uses the autobiographical content to denaturalize natural history by focusing on the protagonist's background as a scientist and on the reactions of his interlocutors. García's novel is unique because Ignacio's travel narrative informs Constancia's geocultural imaginary of Anglo-European whiteness and femaleness as represented in her migration narrative. Ignacio's manuscript inhabits Constancia's text and psyche, as suggested by its cursive script, driving her to reproduce the dominant historical narrative of her family history and disavow any information that would counter it.

\section{The embedded travel narrative}

Like Grigg, Ignacio uses science to compensate for a social deficiency. As an only child with a tin ear, Ignacio could not fully interact with his musical family. Instead, as a child, he began the lifelong activity of travel within Cuba-expeditions into the countryside to hunt and collect birds. How else, he says to his mother, could he "understand them" (García 1998, 67)? Ignacio thus develops an approach to knowledge based on a logic of domination in which one must kill something in order to understand it; he later takes this same approach with his wife, with similarly fatal repercussions. In adolescence, Ignacio learns to locate his scientific inclinations within a European geocultural imaginary. He is seduced into an elite Creole worldview when Reynaldo, his father, asks him to substitute for him as lector (reader) in the cigar factory while his father recovers from an illness. Ignacio reads European classics to the one hundred employees at the factorythe Spanish epic poem El Cid, as well as works by Charles Dickens and Victor Hugo (30). Ignacio's subjectivity, shaped by his father, a Spanish immigrant, indicates his epistemic dependence on Spain. At this stage in his development, he inhabits the site of colonial difference by aligning himself with the European colonizer. Soon, however, he will inhabit the site of difference as a nation builder through his construction of natural histories. 
By choosing biology as a profession, Ignacio, like Grigg, uses positivist science as the operative paradigm in his social projects at the family and national levels. As Constancia recalls, "Papi could identify a creature's essential habits - its food preferences and mating rituals, its nurturant or aberrant behavior" (García 1998, 134). But, by contrast, he also believes that "human beings are distressingly unpredictable" (García 1998, 134). Ignacio implements the whole relay of metaphorical possibilities associated with the survival of the fittest and with blood in order to translate the predictability of natural laws into the social arena, laws over which he is master. This is illustrated in two episodes, one occurring in Ignacio's adolescence and the other during his freshman year at the university.

Ignacio's encounter with a leatherback turtle occurs shortly after his thirteenth birthday. Consoling him "for love's failure" in his first romantic relationship, Igancio's parents take him to the south coast of Cuba for his first solitary expedition (García 1998, 91). There, he observes the very rarely sighted eight-foot turtle deposit her eggs in the sand, erase the nest tracks, and return to sea (91). Angry at the abandonment, which he views in the context of his recent experience, Ignacio sits on the nest for twentyfour hours to ensure species survival. As he says, "What choice did I have?" (93). Ignacio's social and emotional deficiencies, like Grigg's, cause him to seek refuge in nature. But Ignacio denies that nature is also unpredictable. To preserve the laws of predictability, Ignacio does not just observe the object (an object that he identifies with and therefore perceives as the fittest); he tampers with it, thereby ensuring that the law of survival of the fittest specimen be met. Ironically, however, his actions bring to light the fact that this specimen, like himself, is not as superior as he might like to believe.

Ignacio acts in conformity with the metaphorical framework of the fittest again when, spurred by a sense of rivalry toward his peers, he applies for the coveted position of field assistant for the renowned Harvard biologist Dr. Samuel Forrest, who has recently arrived at the University of Havana. His winning response-parasites - to Forrest's query about the animal species he most admires, is something the American scientist finds satisfying, probably due to parasites' instrumental approach to survival (García 1998, 115). As Ignacio explains, by attaching itself to a stronger host, the parasite ensures its survival. It is more like humans than other species because it depends on a variety of receptacles for its survival. This ability allowed humans to "plan for the future, to predict the behavior of matter in ways wholly distinct from animals" (116).

The imagery of blood informs Ignacio's knowledge of parasitism, concretizing his geocultural imaginary. García denaturalizes the concept of parasitism by contextualizing it, revealing it not as universal but as de- 
rived from a locus of enunciation that allows Ignacio to use his knowledge of the concept instrumentally. From a naturalistic perspective, the biologist perceives the parasite-host relationship occurring between organisms living in constant contact. The parasite lives in the tissues and blood of a host "that is larger, stronger, and faster than itself, with minimal disturbance" (García 1998, 116). García does not use the metaphor of blood as Montero does, to prove superiority of European (white) male ancestry, but rather employs it to indicate the actual exploitative mechanisms by which the settler class used the European cultural imaginary to survive off of those already inhabiting the same environment.

Ignacio's parasitic interactions with his peers are palpable. As a doctoral student in biology at the University of Havana, Ignacio remains indifferent to the heroic actions of his peers and his mother as they participate in protests against General Gerardo Machado's brutal regime. He prospers, thanks to the university resources in the locality that the students fight for, while remaining willfully ignorant of the consequences of his prosperity, much like the North Americans who funded Machado's regime (García 1998, 152). Ignacio's relationship to Blanca follows a similar pattern. At the university, he admires her instinct and intuition, but not her scientific abilities. He competes against other suitors for her attention, but once married, the qualities he once admired threaten his plans for the future. Seeking a predictable and passive receptacle, he refuses to pay her for her work on his projects while forbidding her to seek employment elsewhere. As he says, "Frankly, I no longer saw the need. . . I had certain expectations for my wife" (225).

Ignacio inhabits the locus of colonial difference at a different juncture than that of his father or Grigg. While Reynaldo lives as if he were in Europe, preserving Spanish culture through his job at the El Cid Cigar factory, his violin concerts, and cuisine, Ignacio forms what Pratt calls a "split subjectivity" $(2008,465)$ as a member of the Creole elite. As Pratt affirms, "Their reality is here, but it is guided by the geocultural imaginary of an elsewhere" (465). For Ignacio, that means not just introducing Spanish cultural customs into his everyday life, as his father did, but going further by making the elsewhere the cognitive-symbolic inscription of the nation.

As Teresa Derrickson notes, Ignacio begins his confessional narrative with Cuba's independence from Spain. The history of his life becomes the making of a national identity (Derrickson 2007, 481-84). Ignacio uses his research to create a natural national history of Cuba by writing books about Cuba's rare animal species, such as Cuba's Dying Birds and Cuba: Flora and Fauna (García 1998, 11; Derrickson 2007, 483). Ignacio legitimizes Cuba as a nation through his dissemination of Cuba's flora and fauna while naturalizing his own privileged position within the nation. 
Before shooting her, Ignacio describes how he views Blanca: as a delicateboned bird (García 1998, 183). She is another of his rare species. Yet she does not act as the object or body of his knowledge but rather as a subject or elusive mind that his science cannot penetrate or master. Because he cannot predict her behavior, he perceives her as a threat that undermines his view of the social world as contiguous with the natural world and jeopardizes his efforts to use scientific knowledge to underwrite the Cuban nation.

Blanca initially insists on a salary, applies for positions elsewhere, and even considers moving to the United States to work. But after mastering Ignacio's science, Blanca starts to reject the positivist epistemology on which it is based. During an outing with her young daughter Reina, Blanca overtly expresses her disdain for Ignacio's knowledge. She tells Reina that the lights Columbus saw from the Santa María, which he thought were land, were merely Bermuda fireflies in one of their biannual mating seasons, when they "turn miles of the Caribbean a phosphorescent green" (García 1998, 98). She concludes this story with a lesson on the risks of relying on observational evidence: "You don't know how much of what you see, mi hija [my daughter], you never see at all" (98).

Blanca finally abandons Ignacio and Constancia, their newborn child. When she returns two and a half years later, pregnant with Reina, Ignacio notes her visible identification with her African heritage, passed down from her mother, a mulatta. He imagines that the "giant mulatto, tall as a lamppost and with incalculable heft" loitering near their house is his wife's lover and the father of Reina (García 1998, 265). He is wearing a beaded bracelet in a red and white pattern, the colors of the Santería god Eleggúa, the same colors as the beaded necklace Blanca wears upon her return (Irizarry 2006, 210). Ignacio resists being put in the demeaning position of having to compete with the "giant mulatto" in order to win back Blanca's love or convince her of the superiority of the scientific worldview, as opposed to a cosmology linked to Cuba's African substratum, the cultural legacy of Blanca's mother. To do so would require him to recognize his embodied existence, knowledge, and worldview as coeval with those of the mulatto and to consider the possibility that he might not be a viable contender in Blanca's eyes. He opts instead to repress the possibilities that her actions have provoked by annihilating her.

\section{Constancia's transmigration narrative}

Constancia's migration narrative is underpinned by Ignacio's confessional autobiography. His narrative is the discursive nexus between the past and 
the present and between two geocultural domains, Cuba and the United States. Ignacio's narrative begins to haunt her while she is in New York, where she lives and works as a cosmetologist. Her nostalgia grows. It is a homesickness not for Cuba per se but for the "spiteful inheritance" she feels she must shoulder: the mandate to maintain a lost prototype of $\mathrm{Cu}$ ban womanhood she believes her mother personified (García 1998, 130). ${ }^{4}$ Constancia, now in middle age and becoming increasingly apprehensive of change or disorder, wishes to preserve her body's youthfulness as a way of preserving the past. But she seeks a particular version of the past: an idealized, eternal Cuban nation that Cuban women like her mother embodied, as manifested in their pale skin and fine bone structure, as well as, in the case of her mother, eternal youth, since her mother died at the age of thirty-four. This desire takes root in her subconscious and intensifies to such a degree that one day Constancia awakens to discover "that her mother's face had replaced her own" (131). While she sees her mother's youthful face in the mirror in the place of her aged one, in her everyday life, her father's geocultural imaginary shapes who that Cuban female subject should be.

Constancia, as her name indicates, remains faithful to the cognitive horizon of the dominator. In her condition of displacement, Constancia exercises the coloniality of gender, using that horizon to colonize the imaginary of other Cuban-American female migrants. Her migration and travel from New York to Miami is the repetition of colonial travel linked to nation building. She seeks to exert control over the gendered other of the dislocated Cuban nation. By affixing her mother's image on the beauty products she concocts and sells, she transmits the message that the Creole bourgeois female subject is gatekeeper of the nation (Derrickson 2007, 487).

To retrieve the youthful face she associates with her mother, and to retrieve her perception of Cuban women's historical identity, she seduces the Miami cubanas into purchasing a self-concept of the pre-Castro, white, middle-class Cuban woman. Using her cosmetological science to mix emollients made out of the natural flora of Cuba, she creates and markets "a full complement of face and body products for every glorious inch of Cuban womanhood" to have her compatriots "embody the exalted image Cuban women have of themselves: as passionate, self-sacrificing, and deserving of

\footnotetext{
${ }^{4}$ For an analysis of nostalgia in relation to Cubans' negotiation of identity under conditions of displacement in García's novel Dreaming in Cuban (1992), see Dalleo and Machado Sáez (2007).
} 
every luxury" (García 1998, 131). Constancia uses US capitalism coupled with Ignacio's parasitic method as her resources to exploit Cuban women's nostalgia.

As Tommie Shelby shows, Karl Marx developed a naturalized concept of exploitation by using the metaphor of parasitism to reveal connections between social exploitation and its counterpart in the natural world (Shelby $2002,387)$. Shelby highlights a model of parasitism applicable to coloniality, which he calls the "process model" (389). This model plays out through two activities: foraging, linked to the host, and scrounging, linked to the parasite. The forager-host invests energy to get the desired resource, food, or protection, while the scrounger-parasite extracts the resource from the forager's control. Shelby explains that parasitologists have identified three scrounger strategies: first, usurpation, whereby the parasite forcibly takes possession of the resource; second, deception, whereby the parasite appropriates the resource because its molecular structure is the same; and finally, stealth, whereby the activity of the parasite remains undetected (389-90).

Constancia's strategy is deception. A newcomer to Miami, she expresses superiority toward the Miami cubanas, rejecting "their habit of fierce nostalgia, their trafficking in the past like exaggerating peddlers" (García 1998, 45-46). Still, she shares their racial-ethnic, gender, and class roots, which allows her to function as a deceiver. As scrounger-parasite, she sells her creams to this group, the forager-host. Benefiting from their nostalgia, she takes control, using their forager-host efforts for her own parasitic needs, thereby reducing her own efforts to retrieve her mother's face. Constancia's interaction is exploitative because it is patterned after her father's interaction with her mother decades earlier. Constancia's deceiver strategy is also aligned with the usurpation and stealth strategies of the US government. The government used the forager-host efforts of Cuban exiles for its parasitic needs. It prepared the Cuban exiles for the Bay of Pigs invasion, in which the men in Constancia's family were in some way involved, in order to rid the hemisphere of communist rule. In effect, Constancia's strategies to maintain the nation are imbricated with the neocolonial strategies of the US government.

Returning to Constancia's entrepreneurial activities, it could be argued that she was not exploitative, given the wealth of the first wave of Cuban exiles. The economic livelihood of Constancia's clients is not jeopardized by their purchase of her products. Following Shelby, however, the notion of exploitation in a parasitic relationship is defensible if the activities of the exploiter are costly to the exploited because they destroy something of meaning to the exploited (Shelby 2002, 396). The Miami cubanas experience a particular cost - an epistemic one-because the self-concept of the female bourgeois national subject is a lie, an identity based on a false mem- 
ory. As Reina reminds Constancia, “memory is little more than this: a series of erasures and perfected selections" (García 1998, 163).

While Ignacio initially seems to exert a decisive and overpowering influence on Constancia and Reina, a different framework for being and knowing begins to haunt the siblings. This framework enters into tense dialogue with the scientific one, moving the characters from the paternal, colonial inheritances of knowledge to a heterogeneous model based on the maternal epistemological legacy. García uses myth to explain Reina's transculturation, her emergent double positioning that facilitates the recovery of a more accurate, heterogeneous history of the nation. The reader is first introduced to Reina when she is exercising her labor as an electrician. She has been sent to the village of Cobre to repair a defective pump and then use it to drain a flooded mine. The mine is the site where, three hundred years earlier, slaves extracted ore for the nation's artillery and where, one century later, they rebelled against their masters, eventually becoming free citizens.

Before arriving at the mine, Reina stops at the local chapel to pray to the Virgen de la Caridad del Cobre (Our Lady of Charity) before attempting the difficult task. The virgin is a heterogeneous figure pertaining to Santería, a syncretic belief system derived from the merging of the Yoruban divinities or orishas of West Africa and corresponding Catholic saints. Like vodou, Santería highlights the power of the orishas. The family is a lineage encompassing living members as well as the dead ancestors. The orisha is, in effect, a saintly ancestor who protects and empowers family members within concrete historical circumstances by temporarily possessing them (Barnet 1997, 81). The figure that Reina venerates is connected to and embodies her mother. ${ }^{5}$ She is the brown virgin, patron saint of Cuba, incarnation of Oshún, the goddess of love and overlay of the Virgin Mary. While initiating the repair just minutes after her veneration of the virgin, Reina is thrown forty feet into the air and entangled in a tree, remaining in "another kingdom entirely" (García 1998, 17). A "divine intervention" has occurred, the narrator informs the reader (16). Chango, the Santería spirit of lightening and husband of Oshún, has hurled bolts of lightning at Reina, helping her, as his devotee, to gain self-knowledge by resuscitating the repressed history of her mother, which is in turn connected to the repressed history of the African slave rebellion.

Reina now begins to recover a historical identity from which she has been decoupled. The mahogany tree in which she is caught has a salvific function (Aguerrevere 2005). Her entanglement facilitates her rebirth. During her

${ }^{5}$ For a detailed account of the transculturation of Blanca into Oshún, see MarmolejoMcWatt (2005). 
subsequent hospitalization, Reina undergoes surgery in order to heal her severely burned body. The donated patches of skin grafted on her body come from strangers and friends alike. She now reflects the diverse Cuban historical identities in all of the various shades of the Afro-Cuban and the mulatta. The physical change is accompanied by a symbolic transformation as reflected in her voice. It is charged with lightning, Chango's power (García 1998, 36). The disavowed now returns. Reina comes to contemplate the basic principles of Santería that are already embedded within her and that had drawn her to her lover Pepín, a santero or diviner. Like him, the narrator tells us, Reina believes that the world is "a grand interdependency," where "nothing . . . can ever be dismissed" (39).

When Reina returns home, she begins to notice that her father's old apartment in Cuba renders a unilateral national history and their family's positioning within it. As Maya Socolovsky $(2000,159)$ notes, the stuffed and preserved birds mounted on the walls in the study serve as false memorials that preserve Ignacio's place as the elite progenitor of the nation. They overwrite his cowardly withdrawal from the student struggles of his youth, his murder of Blanca, and his lies.

Reina reflects back on the illusoriness of the national project. She considers it in light of the present and future of the anticolonial project of revolutionary Cuba, the present state of which is epitomized in the labor of sex work that her daughter, Dulcita, is obliged to carry out in order to eke out an existence. This social fact highlights, as Derrickson notes, the failure of Cuba's socialist experiment during the Special Period, when the conclusion of the Cold War resulted in the Soviet Union's withdrawal of financial support to Cuba in the early 1990s. It also shows the effects of the economic marginalization of Cuba from world trade. In this revolutionary phase, Fidel Castro was forced to yield to American and international financial systems and industries, which included the legalization of the dollar and the encouragement of international tourism, both of which paved the way for sex tourism, Cuba's biggest contemporary industry (Derrickson 2007, 48). Coloniality, Reina and Dulcita would discover, finds new ground on which to exert its power within this apparently anticolonial terrain.

These more conscious reflections facilitate Reina's readiness to encounter her sister. In Miami, meanwhile, Constancia visits the Santería diviner Oscar Piñango to find out how to rediscover her true face. He, like Reina, prays to the Virgen. He throws the cowrie shells, interpreting the design in which they fall to determine the orishas' message because it is through the shells that the orishas speak (García 1998, 111). He advises 
that Constancia must uncover what has been suppressed from or buried in her father's archive. To break the family curse, she must travel-return to "where the grave was first dug" (117).

Through decolonial travel, the sisters begin the work of recovering the true face of their family and of their nation, one that has to be constructed collectively. While accompanying Constancia on the first leg of her boat trip back to Cuba, via Key West, Reina seeks to separate the truth from the lies Ignacio has told them about their mother's death, following the instructions of the santero. It was not an accidental drowning or shooting death, Reina tells Constancia, but murder. Their father shot Blanca in the throat. The first attempt at dialogue results in a violent confrontation. Constancia tries to drown her sister, but breaks the predator-prey family pattern by dragging her back into the boat. Unlike Grigg and Ignacio, Constancia is motivated to dispel her error. She takes Reina's history seriously by acknowledging that Ignacio’s is “all a mock history” (García 1998, 276).

In her return to the family home in Camagüey, Constancia fully recognizes her error: Cuban women do not look like the female bourgeois image affixed to the jars of her products. Her own skin "is too smooth by local standards, too protected from the sun" (García 1998, 190). Upon retrieving her father's manuscript, she also finds a little "fragment of bone" that her mother always carried on her wrist (186). The bone has syncretic value. Blanca did not carry the bone to venerate a Catholic saint. Rather, she transculturated it as she did herself. She is aligned with Olokún, the patron goddess of the descendants of Africans carried away during the Middle Passage, associated with the Virgin of Rule and the Immaculate Conception. The human bone shard represents a suppressed history-the dismembered bodies discarded on the ocean's floor, the "'collateral damage' from the trade between three continents: Africa, the Americas and Europe" (Bellagarde-Smith 2005, 1).

\section{Toward a decolonial feminism}

García and Montero's narratives are palimpsests. By locating their characters at the fractured locus of colonial difference, they elaborate the ideological interests mediating the global, hegemonic histories of colonial difference but overwrite these histories by reinscribing them from the subaltern perspective. As readers, we must labor to decode as unnatural the dominant sense-making mechanisms in the text, that is, the metaphorical apparatuses that function as background assumptions driving the dominator's actions; we are also encouraged to aid in unmasking their op- 
pressive logic, our coparticipation in it, and the distortions in our own historical identities.

Montero and García show how the ongoing forces of coloniality resurface within social-scientific dimensions of travel and are reinserted within various temporal-spatial political domains-colonialism, nationalism, and neocolonialism - as human subjects within them reinvent coloniality's logic. Nonetheless, the emergence of decolonial border thinkers in these narratives provides positively constituted templates of social life in modernity. Thierry, Blanca, Reina, and Constancia learn to produce knowledge not through mastery but through the release of mastery-not through solipsism but through relationality. They view knowledge not as abstract and universal but as emerging from historical identities. They pursue knowledge not for instrumental but for ecological ends. The ecological approach to science, as Sofia Kearns (2006, 119) notes in her study of Montero's novel, takes into account the realm of the social in the scientific pursuit of nature by being accountable to the dilemmas of those communities who inhabit the places that scientists visit in their travels. These characters understand knowledge not just as the pursuit of facts but as linked to other values, including wisdom, compassion, and understanding and as incorporating social and self-knowledge. Finally, their epistemological assumptions are based not on observational evidence alone but also on interpretive processes that require complex understandings of social contexts. These knowledge practices are undoubtedly valuable for a hemispheric decolonial feminism. They will not only help us to decolonize knowledge but also to avert extinction, including human extinction.

Women's and Gender Studies and Department of Sociology Virginia Tech

\section{References}

Acosta-Belén, Edna, and Christine E. Bose. 2000. "U.S. Latina and Latin American Feminisms: Hemispheric Encounters.” Signs: Iournal of Women in Culture and Societv 25 (4): 1113-19.

Aguerrevere, Lucía Anglade de. 2005. "Dar voz al silencio: La mujer y la santería en Las hermanas Agüero de Cristina García, Como un mensajero tuyo de Mayra Montero y Querido primer novio de Zoé Valdés" [Giving voice to silence: Women and Santeria in The Agriero Sisters by Cristina García, The Messenger by Mayra Montero, and Dear First Love by Zoé Valdés]. PhD dissertation, Boston College.

Alcocer, Rudyard J. 2005. Narrative Mutations: Discourses of Heredity and Caribbean Literature. New York: Routledge. 
Barnet, Miguel. 1997. "La Regla de Ocha: The Religious System of Santería.” In Sacred Possessions: Vodou, Santeria, Obeah, and the Caribbean, ed. Margarite Fernández Olmos and Lizabeth Paravisini-Gebert, 79-100. New Brunswick, NJ: Rutgers University Press.

Bellagarde-Smith, Patrick. 2005. "Introduction." In Fragments of Bone: NeoAfrican Religions in a New World, 1-12. Urbana: University of Illinois Press.

Benítez-Rojo, Antonio. 1992. The Repeating Island: The Caribbean and the Postmodern Perspective. Durham, NC: Duke University Press.

Bernabé, Jean, Patrick Chamoiseau, and Raphaël Confiant. 1993. Éloge de la Créolité [In praise of Creoleness]. Paris: Gallimard.

Buck-Morss, Susan. 2009. Hegel, Haiti, and Universal History. Pittsburgh: Pittsburgh University Press.

Costa, Claudia de Lima. 2006. "Lost (and Found?) in Translation: Feminisms in Hemispheric Dialogue." Latino Studies, no. 4: 62-78.

Dalleo, Raphael, and Elena Machado Sáez. 2007. The Latino/a Canon and the Emergence of Post-sixties Literature. New York: Palgrave Macmillan.

Dayan, Joan. 1997. "Vodoun, or the Voice of the Gods." In Sacred Possessions: Vodou, Santeria, Obeah, and the Caribbean, ed. Margarite Fernández Olmos and Lizabeth Paravisini-Gebert, 13-36. New Brunswick, NJ: Rutgers University Press.

Derrickson, Teresa. 2007. "Women's Bodies as Sites of (Trans)National Politics in Cristina García's The Agüero Sisters.” Modern Fiction Studies 53(3):478-500.

Farmer, Paul. 2003. The Uses of Haiti. Monroe, ME: Common Courage.

Fischer, Sibylle. 2004. Modernity Disavoned: Haiti and the Cultures of Slaverv in the Aae of Revolution. Durham, NC: Duke University Press.

Francis, Donette. 2010. Fictions of Feminine Citizenship: Sexuality and the Nation in Contemporary Caribbean Literature. New York: Palgrave Macmillan.

García, Cristina. 1992. Dreaming in Cuban. New York: Knopf.

- 1998. The Agüero Sisters. New York: Ballantine.

- 2003. Monkey Hunting. New York: Knopf.

- 2007. A Handbook to Luck. New York: Knopf.

- 2010. The Lady Matador's Hotel. New York: Scribner. 2013. King of Cuba. New York: Scribner.

Hawkins, Mike. 1997. Social Darwinism in European and American Thought, 1860-1945: Nature as Model and Nature as Threat. Cambridge: Cambridge University Press.

Irizarry, Ylce. 2006. "Doubly Troubling Narratives: Writing 'the Oppression of Possibility' in Puerto Rico and Cuba." Comparative American Studies 4(2): 197-217.

Kandiyoti, Dalia. 2006. "Consuming Nostalgia: Nostalgia and the Marketplace in Cristina García and Ana Menéndez.” MELUS 31(1):81-97.

Kaussen, Valerie. 2005. "Fixing History: Race, Nation, and the Symbolics of Servitude in Haitian Noirisme." In The Masters and the Slaves: Plantation Relations 
and Mestizaje in American Imaginaries, ed. Alexandra Isfahani-Hammond, 67-88. New York: Palgrave Macmillan.

Kearns, Sofia. 2006. "Nueva conciencia ecológica en algunos textos femeninos contemporáneos" [New ecological consciousness in some contemporary femaleauthored texts]. Latin American Literary Review 34(67):111-27.

Keller, Evelyn Fox. 1985. Reflections on Gender and Science. New Haven, CT: Yale University Press.

Lugones, María. 2010. “Toward a Decolonial Feminism.” Hypatia 25(4):742-59.

Marmolejo-McWatt, Amparo, 2005. "Blanca Mestre as Ochún in The Agüero Sisters." Afro-Hispanic Review 24(2):89-101.

Mignolo, Walter D. 2000. Local Histories/Global Designs: Coloniality, Subaltern Knowledges, and Border Thinking. Princeton, NJ: Princeton University Press.

Montero, Mayra. 1997. In the Palm of Darkness. Trans. Edith Grossman. New York: HarperCollins.

- 1999. Messenger. Trans. Edith Grossman. New York: HarperFlamingo.

. 2000. The Last Night I Spent with You. Trans. Edith Grossman. New York: HarperCollins. Collins.

2001. The Red of His Shadow. Trans. Edith Grossman. New York: Harper 2005. Captain of the Sleepers. Trans. Edith Grossman. New York: Farrar, Straus \& Giroux.

- 2007. Dancing to "Almendra.” Trans. Edith Grossman. New York: Farrar, Straus \& Giroux.

Page, Kezia. 2011. Transnational Negotiations in Caribbean Diasporic Literature: Remitting the Text. New York: Routledge.

Pérez Firmat, Gustavo. 1990. Do the Americas Have a Common Literature? Durham, NC: Duke University Press.

Pratt, Mary Louise. 1992. Imperial Eves: Travel Writing and Transculturation. London: Routledge.

- 2008. "In the Neocolony: Destiny, Destination, and the Traffic in Meaning." In Coloniality at Large: Latin America and the Postcolonial Debate, ed. Mabel Moraña, Enrique Dussel, and Carlos A. Jáuregui, 459-75. Durham, NC: Duke University Press.

Quijano, Aníbal. 2008. "Coloniality of Power, Eurocentrism, and Social Classification." In Coloniality at Large: Latin America and the Postcolonial Debate, ed. Mabel Moraña, Enrique Dussel, and Carlos A. Jáuregui, 181-224. Durham, NC: Duke University Press.

Rivera, Ángel A. 2001. "Silence, Voodoo, and Haiti in Mayra Montero's In the Palm of Darkness." CiberLetras, no. 4. http://www.lehman.cuny.edu/ciberletras /v04/Rivera.html.

Rosario, Vanessa Pérez, ed. 2010. Hispanic Caribbean Literature of Migration: Narratives of Displacement. New York: Palgrave Macmillan. 
Salvatore, Ricardo D. 2010. "The Postcolonial in Latin America and the Concept of Coloniality: A Historian's Point of View." A Contracorriente [Countercurrent] 8(1):332-48.

Savin, Ada. 2003. "Between Island and Mainland: Shifting Perspectives in Cristina García's The Agüero Sisters.” Revue française d'études américaines [French review of American studies] 96(2):60-73.

Scott, David. 2004. Conscripts of Modernity: The Tragedy of Colonial Enlightenment. Durham, NC: Duke University Press.

Shelby, Tommie. 2002. "Parasites, Pimps, and Capitalists: A Naturalistic Conception of Exploitation." Social Theory and Practice 28(3):381-418.

Socolovsky, Maya. 2000. "Unnatural Violences: Counter-memory and Preservations in Cristina García's Dreaming in Cuban and The Agüero Sisters." Literature Interpretation Theory $11(2): 143-67$.

Szkupinski Quiroga, Seline. 2007. "Blood Is Thicker than Water: Policing Donor Insemination and the Reproduction of Whiteness." Hypatia 22(2):143-61. 